\title{
Effects of essential oils on native and recombinant acetylcholinesterases of Rhipicephalus microplus
}

\author{
Efeito de óleos essenciais sobre acetilcolinesterases nativa e recombinante de \\ Rhipicephalus microplus
}

Everton Gomes Guimarães dos Santos'; Wallyson André dos Santos Bezerra'; Kevin B. Temeyer²; Adalberto A. Pérez de León; Livio Martins Costa-Junior ${ }^{4 *}$ (1); Alexandra Martins dos Santos Soares ${ }^{1}$

\author{
${ }^{1}$ Laboratório de Bioquímica Vegetal, Universidade Federal do Maranhão - UFMA, São Luís, MA, Brasil \\ 2 USDA-ARS Knipling-Bushland U.S. Livestock Insects Research Laboratory and Veterinary Pest Genomics Center, Kerrville, TX, United \\ States of America \\ ${ }^{3}$ USDA-ARS San Joaquin Valley Agricultural Sciences Center, Parlier, CA, United States of America \\ ${ }^{4}$ Laboratório de Controle de Parasitas, Universidade Federal do Maranhão - UFMA, São Luís, MA, Brasil
}

How to cite: Santos EGG, Bezerra WAS, Temeyer KB, Leó AAP, Costa-Junior LM, Soares AMS. Effects of essential oils on native and recombinant acetylcholinesterases of Rhipicephalus microplus. Braz J Vet Parasitol 2021; 30(2): e002221. https://doi.org/10.1590/ S1984-29612021024

\begin{abstract}
This study reports the action of essential oils (EO) from five plants on the activity of native and recombinant acetylcholinesterases (AChE) from Rhipicephalus microplus. Enzyme activity of native susceptible AChE extract (S.AChE), native resistant AChE extract (R.AChE), and recombinant enzyme (rBmAChE1) was determined. An acetylcholinesterase inhibition test was used to verify the effect of the EO on enzyme activity. EO from Eucalyptus globulus, Citrus aurantifolia, Citrus aurantium var.dulcis inhibited the activity of S.AChE and R.AChE. Oils from the two Citrus species inhibited S.AChE and R.AChE in a similar way while showing greater inhibition on R.AChE. The oil from E. globulus inhibited native AChE, but no difference was observed between the S.AChE and R.AChE; however, 71\% inhibition for the rBmAChE1 was recorded. Mentha piperita oil also inhibited S.AChE and R.AChE, but there was significant inhibition at the highest concentration tested. Cymbopogon winterianus oil did not inhibit AChE. Further studies are warranted with the oils from the two Citrus species that inhibited R.AChE because of the problem with $R$. microplus resistant to organophosphates, which target AChE. C. winterianus oil can be used against $R$. microplus populations that are resistant to organophosphates because its acaricidal properties act by mechanism(s) other than AChE inhibition.
\end{abstract}

Keywords: Cattle tick, Rhipicephalus microplus, acetylcholinesterase inhibition, acaricide resistance, essential oils.

\begin{abstract}
Resumo
Este estudo relata a ação de óleos essenciais de cinco plantas na atividade de acetilcolinesterases (AChE) nativas e recombinantes de Rhipicephalus microplus. A atividade enzimática do extrato de acetilcolinesterase nativa suscetível (S.AChE) e resistente (R.AChE) e da enzima recombinante (rBmAChE1) foi determinada. Um teste de inibição da AChE foi utilizado, para verificar o efeito dos óleos essenciais sobre a atividade enzimática. Óleos essenciais de Eucalyptus globulus, Citrus aurantifolia, Citrus aurantium var. dulcis inibiram a atividade de S.AChE e R.AChE. Os óleos das duas espécies de Citrus inibiram S.AChE e R.AChE de maneira semelhante, mas mostraram maior inibição sobre R.AChE. O óleo de E. globulus inibiu a AChE nativa, mas sem diferença entre a S.AChE e a R.AChE; no entanto, $71 \%$ de inibição para rBmAChE1 foi observada. O óleo de Mentha piperita também inibiu S.AChE e R.AChE, mas houve inibição significativa apenas nas concentrações mais altas testadas. O óleo de Cymbopogon winterianus não inibiu a AChE. Estudos adicionais são necessários com os óleos das duas espécies de Citrus que inibiram a R.AChE, devido ao problema de R. microplus resistente aos organofosforados ter como alvo AChE. O óleo de $C$. winterianus pode ser usado contra populações de $R$. microplus, que são resistentes a organofosforados, porque suas propriedades acaricidas agem por mecanismos diferentes.
\end{abstract}

Palavras-chave: Carrapato bovino, Rhipicephalus microplus, acetilcolinesterase, resistência, óleos essenciais.

Received February 4, 2021. Accepted February 18, 2021

*Corresponding author: Livio Martins Costa-Junior. E-mail: livio.martins@ufma.br

This is an Open Access article distributed under the terms of the Creative Commons Attribution License, which permits unrestricted use distribution, and reproduction in any medium, provided the original work is properly cited. 


\section{Introduction}

The tick Rhipicephalus (Boophilus) microplus (Canestrini, 1888) (Acari, Ixodidae) is an economically important ectoparasite of cattle that impairs livestock production systems in tropical and subtropical parts of the world (Pérez de León et al., 2020). The cattle tick $R$. microplus causes direct host damage through its obligate blood feeding habit and is a vector of pathogens, including species of Babesia and Anaplasma that cause bovine babesiosis and anaplasmosis, respectively (Roy et al., 2018). Synthetic chemicals with acaricidal properties are used to treat livestock infestation with $R$. microplus, which is associated with high expenses to farmers (Reginato et al., 2017; Ferreira et al., 2018). In Brazil, the annual economic losses of $R$. microplus is at least $\$ 3.2$ billion (Grisi et al., 2014).

The indiscriminate use of acaricides has made several classes of these chemical agents ineffective due to the development and selection of resistant $R$. microplus populations (Reck et al., 2014; Rodriguez-Vivas et al., 2018). Commercially available classes of acaricides that are used extensively include the organophosphates (OP) and carbamates (CB). Synthetic chemicals in these classes of acaricides exert their inhibitory action on acetylcholinesterase (AChE) (Anderson \& Coats, 2012), which is a hydrolase enzyme that plays a vital role in cholinergic neurotransmission. Inhibition of AChE activity results in hyperexcitability of neurons that leads to seizures, nervous system collapse, and death of the organism (Sharifi et al., 2017; Temeyer, 2018).

Invertebrates have different AChE isoforms (Baxter \& Barker, 2002). In R. microplus three paralogous genes encoding AChEs (rBmAChE1, rBmAChE2 and rBmAChE3) were confirmed and expressed in neural and non-neural tissues (Temeyer et al., 2010). The different biochemical properties of these isoforms and the variation in enzymatic activity between tissues indicates the physiological plasticity of AChE in R. microplus (Temeyer et al., 2020). For example, AChE1 is expressed in the salivary glands, ovaries and synganglion whereas AChE2 is only expressed in the synganglion (Baxter \& Barker, 2002; Temeyer et al., 2013). However, it is known that AChE insensitivity is related to resistance to OPs and CBs, and that in $R$. microplus this is a primary mechanism of resistance to compounds belonging to those classes of acaricides (Temeyer et al., 2010).

Essential oils are among the repertoire of natural products that can be used as alternative treatment against tick infestations because they offer advantages over synthetic acaricides (Hüe et al., 2015; Valente et al., 2017). These include the slow development of resistance by pests, low toxicity to mammals, low environmental impact and reduction of residues in products of animal origin (Abdelgaleil et al., 2009; Salman et al., 2020). As compared to conventional synthetic acaricides, essential oils that are efficacious can enhance the safety of treatment for livestock infested with R. microplus (Gross et al., 2017; Wang et al. 2019). The composition of essential oils includes volatile secondary metabolites known for their significant role in plant defense mechanisms (Silva Lima et al., 2018). Essential oils are a complex mixture of substances from various chemical families, however the most common compound found are terpenes (mono and sesquiterpenes) and phenylpropanoids (Dhifi et al., 2016; Salman et al., 2020).

Essential oils are known to have pesticidal and repellent properties (Pinto et al., 2015; Soares et al., 2016; Carroll et al., 2017) and some essential oils have also been investigated for their inhibition capacity of AChE (Salleh \& Khamis, 2020). As example, essential oil of Origanum syriacum inhibited AChE of Culex quinquefasciatus (López et al., 2019), and Eucalyptus globulus essential oil inhibited AChE of Rhipicephalus annulatus (Arafa et al., 2020). However, there are no scientific reports on the ability of essential oils from Eucalyptus globulus, Citrus aurantifolia, Citrus aurantium var. dulcis, Mentha piperita, and Cymbopogon winterianus to inhibit AChE from R. microplus. In this study we investigated the action of essential oils from those plants on AChE activity in larvae of acaricide susceptible and resistant strains of $R$. microplus, and on rBmAChE1.

\section{Materials and Methods}

\section{Tick populations}

Ticks from two populations of R. microplus, a susceptible (Porto Alegre strain) and other resistant (resistant to organophosphate, synthetic pyrethroids, phenylpyrazole, amidinic, macrocyclic lactone, and benzoylphenyl urea derivatives - Jaguar strain) (Reck et al., 2014) were obtained by artificial infestations of cattle, which were not recently exposed to acaricide. The experimental procedures were approved by the animal research ethics committee of the Federal University of Maranhão (UFMA) under protocol number 23115.008186/2017-18.

Fully engorged females were naturally detached, and then were collected, washed with distilled water, dried on filter paper, weighed and separated into groups containing ten specimens each (maximum weight difference 
was $\pm 0.5 \mathrm{~g}$ ). The ticks were incubated $\left(27^{\circ} \mathrm{C}\right.$ and relative humidity $\left.\geq 80 \%\right)$, for $14-21$ days, for oviposition (Silva Lima et al., 2018) and subsequent hatching to produce larvae used in preparation of crude larval extracts.

\section{Obtaining the native and recombinant AChEs}

In order to extract the multiple AChEs present in the larval extracts, $R$. microplus larvae were macerated using a mortar and pestle for $5 \mathrm{~min}$ in $100 \mathrm{mM}$ sodium phosphate buffer, $\mathrm{pH} 7.0$, containing $5 \mathrm{mM}$ EDTA, 0.5\% (v/v) Triton X-100, and $5 \mu \mathrm{L} . \mathrm{mL}^{-1}$ protease Inhibitor mix (Sigma-Aldrich, St. Louis, MO, USA), at a 1:25 ratio (larva weight/ buffer volume). The extract was left standing for $25 \mathrm{~min}$ at $4{ }^{\circ} \mathrm{C}$ and centrifuged at $4{ }^{\circ} \mathrm{C}$ for 30 min at $15.000 \times g$. The supernatant was recovered, stored at $4{ }^{\circ} \mathrm{C}$, and used as a source of AChEs of susceptible and resistant strain named respectively, native susceptible AChE extract (S.AChE) and native resistant AChE extract (R.AChE).

The recombinant enzyme (rBmAChE1) was obtained according to Temeyer et al. (2010). Briefly, total RNA was isolated from pooled larvae of susceptible strain. Gene-specific primers were utilized to direct synthesis of first-strand CDNA from RNA template using Reverse Transcriptase, and complete BmAChE1 coding regions were amplified by high fidelity PCR from CDNA, sequenced, and expressed in baculovirus vectors. Recombinant expression clones were assembled, sequenced, and expressed in baculovirus infected Sf21 cell cultures.

Protein concentration was determined using bovine serum albumin (BSA) as standard (Bradford, 1976). Results were expressed in milligrams of proteins per milliliter $\left(\mathrm{mg}^{\mathrm{mL}} \mathrm{mL}^{-1}\right)$.

\section{Determination of AChE activity}

The S.AChE, R.AChE and rBmAChE1 activity was determined according to Ellman et al. (1961), modified as described by Li et al. (2005). The reaction mixture consisted of $10 \mu \mathrm{L}$ of the S.AChE or R.AChE (1.5 mg protein $\mathrm{mL}^{-1}$ final concentration) or rBmAChE1 diluted $30 \mathrm{X}$ with buffer ( $50 \mathrm{mM}$ sodium phosphate, $\mathrm{pH} 7.5$ ), $100 \mu \mathrm{L} 50 \mathrm{mM}$

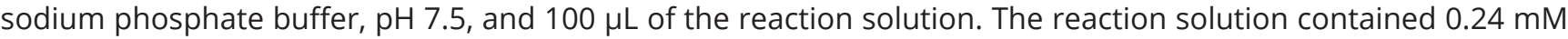
acetylthiocholine iodide (Sigma-Aldrich) and $0.64 \mathrm{mM} \mathrm{5,5'-dithiobis-(2-nitrobenzoic} \mathrm{acid)} \mathrm{(DTNB)} \mathrm{(Sigma-Aldrich)}$ prepared in the above sodium phosphate buffer. In the blank sample, the AChE aliquot was replaced by the buffer. Reaction was conducted in a 96 well microplate for $30 \mathrm{~min}$ and monitored every $5 \mathrm{~min}$ by recording the absorbance (Abs) at $405 \mathrm{~nm}$ (Microplate Reader, Biochrom). Activity was calculated using the equation: Activity (abs/mL/min) = $\left[\left(T_{30}-T_{0}\right) / 30\right] \times 100$, where $T_{0}$ and $T_{30}=$ sample absorbance - blank absorbance measured at zero and 30 min reaction. Only linear reactions throughout the monitoring period were considered.

\section{Inhibition of AChE activity}

Essential oils from E. globulus (chemical composition - 83\% 1.8-cineol, 9\% limonene, 4\% alfa-pinene, 3\% p-cimene), C. aurantifolia (chemical composition - $57 \%$ limomene, $14 \%$ y-terpinene, $12 \% \beta$-pinene, $2 \%$ a-pinene, $1.5 \%$ mircene, $1.5 \%$ geranial), C. aurantium var. dulcis (chemical composition - $96 \%$ limonene, $1.8 \%$ mircene, $0.5 \%$ a-pinene, $0.3 \%$ sabinene), M. piperita (35\% menthol, 26\% menthone, 6.0\% 1.8-cineol, 5.0\% isomenthone, $5.0 \%$ methyl acetate, $4.0 \%$ neomenthol) and $C$. winterianus (chemical analysis was not performed) were commercially purchased (Ferquima). The chemical analysis were performed by company and informed to the authors. The essential oils were individually diluted in ethanol to $20 \mathrm{mg} \cdot \mathrm{mL}^{-1}$ (stock solution). From the stock solution, an essential oil solution at $2 \mathrm{mg}$. $\mathrm{mL}^{-1}$ was prepared in $50 \mathrm{mM}$ sodium phosphate buffer, $\mathrm{pH}$ 7.5. The final essential oil concentrations tested were $1.00,0.67$, $0.44,0.30,0.20,0.13,0.088,0.058,0.039,0.026,0.017$ and $0.012 \mathrm{mg} \cdot \mathrm{mL}^{-1}$. These concentrations were selected by a preliminary pilot test performed.

The AChE inhibitory activity was evaluated by mixing $10 \mu \mathrm{L}$ of the S.AChE, R.AChE or rBmAChE1 with $100 \mu \mathrm{L}$ of the essential oil and $100 \mu \mathrm{L}$ of the reaction solution described above. Propoxur (Sigma-Aldrich) was used as a positive control. It was similarly prepared as the essential oil, but at 0.25, 0.05, 0.025, 0.005, 0.0025 and 0.0005 $\mathrm{mM}$ final concentrations (Prado-Ochoa et al., 2014). In the negative control, essential oils were replaced by the phosphate buffer and ethanol. Reactions were conducted in a 96 well microplate for 30 min and monitored every $5 \mathrm{~min}$ by recording the absorbance (Abs) at $405 \mathrm{~nm}$ (Microplate Reader, Biochrom).The percentage of enzyme inhibition was calculated by comparison with the negative control as follows: AChE inhibition (\%) = $100-[(A s / A c)$ $\times 100]$, where: $A s=A C h E$ activity for each concentration; $A c=$ negative control (AChE activity without essential oil). Only linear regression reactions throughout the monitoring period were considered. 


\section{Statistical analyses}

The data were obtained from the triplicate inhibition assays of two independent experiments for each essential oil on the S.AChE and R.AChE and rBmAChE1. The data were initially transformed to log $(X)$ and normalized; subsequently, nonlinear regression was performed to obtain the IC50 (50\% inhibition concentration) and the F test was used by pair to compare the curves. All analysis were performed using the GraphPad Prism 7.0 software (GraphPad Inc., San Diego, CA, USA).

\section{Results and Discussion}

Acaricidal and repellent activities, and egg hatch inhibition are among the biological properties against ticks reported for essential oils of plant species in the genus Citrus (Pazinato et al., 2016; Stefanidesova et al., 2017; Vinturelle et al., 2017). In our experiments C. aurantium var. dulcis and C. aurantifolia inhibited S.AChE and R.AChE in varying degrees. Stronger inhibition against R.AChE was exhibited by C. aurantifolia oil $(64.0 \pm 13.1 \%)$ at $0.44 \mathrm{mg} \cdot \mathrm{mL}^{-1}$ and C. aurantium var. dulcis (49.8 $\pm 8.5 \%$ ) at $0.67 \mathrm{mg} \cdot \mathrm{mL}^{-1}$. However, the inhibition decreased at highest concentrations (Figures $1 \mathrm{~A}$ and 1B). There was statistically significant difference among IC50 of S.AChE, R.AChE and rBmAChE1 after treatment with C. aurantium var. dulcis, and C. aurantifolia.
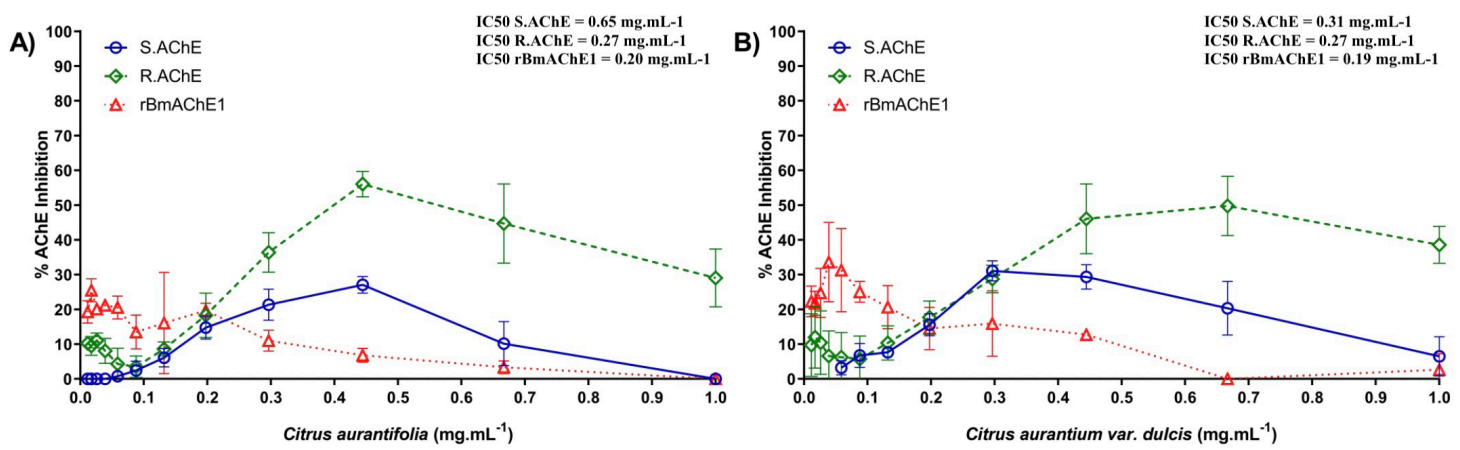

C)
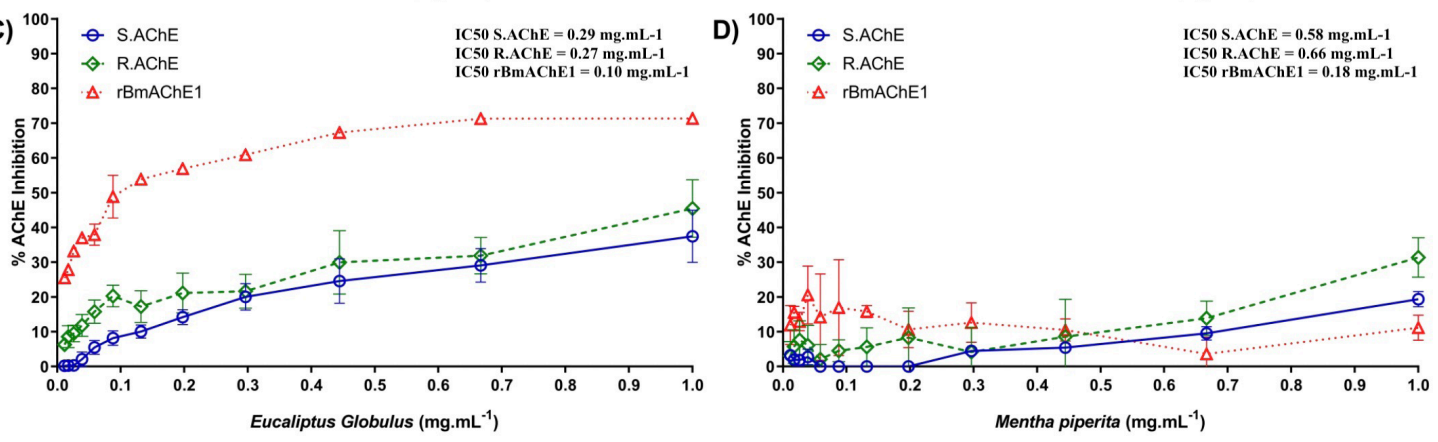

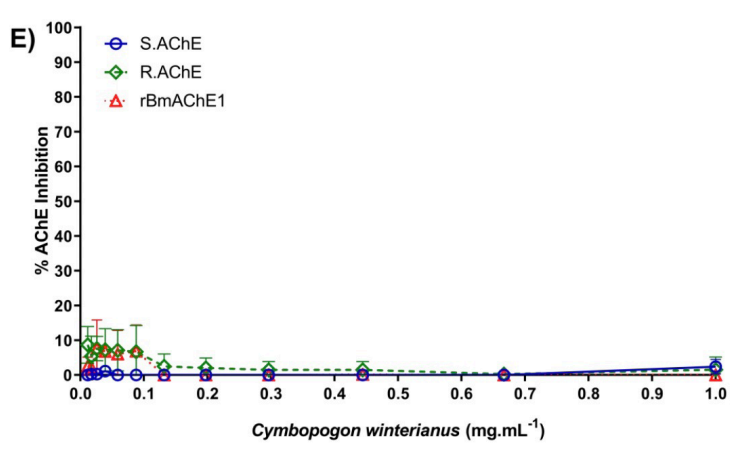

Figure 1. Effect of different concentrations of essential oils $\left(\mathrm{mg} \cdot \mathrm{mL}^{-1}\right)$ on the acetylcholinesterase activity of $R$. microplus expressed as percentage of inhibition (\%) and its. The essential oils used (A) Citrus aurantifolia; (B) Citrus aurantium var. dulcis; (C) Eucalyptus globulus; (D) Mentha piperita, and (E) Cymbopogon winterianus. S.AChE: Native susceptible AChE extract; R.AChE: Native resistant AChE extract; rBmAChE1: Recombinant enzyme; IC50: 50 percent inhibitory concentration. Each point represents the mean of the values obtained from two independent experiments performed in triplicate. 
The Citrus oil inhibition profiles for S.AChE and R.AChE reported here suggest that structural difference between the AChE of susceptible and resistant tick larvae result in different sensitivities to Citrus oils, which is consistent with the known mechanism of OP resistance in R. microplus associated with AChE insensitivity (Temeyer, 2018). Bioassays are warranted to determine if our in vitro results translate into acaricidal and/or repellent activity against $R$. microplus by the oils of $C$. aurantifolia and $C$. aurantium var. dulcis. By comparison, monoterpenes in oils of other Citrus plants have been shown to be active against $R$. microplus and Dermacentor reticulatus (Pazinato et al., 2016; Stefanidesova et al., 2017). In this regard, the monoterpene limonene has been shown to be acaricidal against R. microplus (Ferrarini et al., 2008; Vinturelle et al., 2017).

Eucalyptus globulus oil inhibited $37.5 \pm 7.5$ and $45.5 \pm 8.3 \%$ of S.AChE and R.AChE at 1 mg.mL ${ }^{-1}$, respectively. Significant difference in inhibitory activity was observed between the S.AChE (IC50 $\left.=0.29 \mathrm{mg} \cdot \mathrm{mL}^{-1}\right)$ and R.AChE $\left(\mathrm{IC50}=0.27 \mathrm{mg} \cdot \mathrm{mL}^{-1}\right)$. However, the oil from E. globulus strongest inhibited the rBmAChE1 with IC50 of $0.10 \mathrm{mg} \cdot \mathrm{mL}^{-1}$ (Figure 1C). Because the other oils tested did not inhibit rBmAChE1, we hypothesize that differences between their components afford them various levels of inhibitory activity against the $\mathrm{AChE}$ isoforms considering that $R$. microplus has at least three functional AChEs (Temeyer et al., 2010), and that the larval extracts obtained in this study likely contained the three native AChEs. The pesticidal activity of this oil was associated with a high content of 1.8-cineole, also known as eucalyptol (Miresmailli et al., 2006; George et al., 2009). In a previous study with $R$. microplus, eucalyptol showed greater AChE inhibition against the resistant strain $\left(\mathrm{IC}_{50} 0.36 \mathrm{mg} \cdot \mathrm{mL}^{-1}\right)$ than the susceptible strain (IC $3.41 \mathrm{mg}_{50} \mathrm{~mL}^{-1}$ ) (Cardoso et al., 2020). Furthermore, $0.01 \mathrm{M}$ of eucalyptol inhibited AChE $64.9 \%$ in larvae of the beetle Tribolium castaneum (Abdelgaleil et al., 2009). The observed differences in rBmAChE1 inhibition by essential oils are strongly suggestive as to their role in the total activity of AChE present in tick larvae, indicating that $\mathrm{rBmAChE1}$ is only partially responsible for the total AChE pool activity, since C. aurantifolia and C. aurantium var. dulcis oils predominantly target other tick AChEs, in contrast, E. globulus oil which inhibited rBmAChE1.

Mentha piperita (popularly known as peppermint) essential oil also showed AChE inhibition. The inhibition rates recorded at the highest concentration ( $\left.1 \mathrm{mg}^{\mathrm{mL}} \mathrm{mL}^{-1}\right)$ tested were $31.4 \pm 5.7 \%, 19.4 \pm 2.2 \%$, and $11.2 \pm 3.6 \%$ for the R.AChE $\left(\right.$ IC50 $\left.=0.58 \mathrm{mg} \cdot \mathrm{mL}^{-1}\right), \mathrm{S} \cdot \mathrm{AChE}\left(\mathrm{IC50}=0.66 \mathrm{mg}^{\mathrm{mL}} \mathrm{L}^{-1}\right)$, and rBmAChE1 (IC50 $\left.=0.18 \mathrm{mg} \cdot \mathrm{mL}^{-1}\right)$, respectively (Figure 1D). These results suggest that AChE inhibition was caused by a relatively minor component of the peppermint oil or the majors component had low activity. Peppermint oil is acaricidal, repellent, and known to contain menthol and menthone as major compounds (Chagas et al., 2016). M. piperita oil also has fumigating action and this activity is promoted by the rapid volatilization of 1.8-cineole (Mkolo et al., 2011).

Cymbopogon winterianus (popularly known as Citronella) essential oil is widely used and commercialized for its repellent and acaricidal activity. These properties of citronella oil are attributed to the presence of volatile substances such as citronellal, eugenol, geraniol, which are major components that act synergistically (Olivo et al., 2008; Singh et al., 2014a, b). Citronella oil did not inhibit the $R$. microplus AChEs in our experiments (Figure 1E) and the IC50 were not obtained. Thus, $C$. winterianus oil can be used against $R$. microplus populations that are resistant to carbamates and organophosphates because its acaricidal properties act by mechanism(s) other than AChE inhibition.

Although the oils tested in this study had shown to be active against ticks of different species including $R$. microplus (George et al., 2009; Singh et al., 2014b; Chagas et al., 2016), questions remained on their mode of action. The pesticidal effect of essential oils results from the synergistic interactions between their bioactive components (Isman, 2015). Essential oil components can act simultaneously on different molecular targets (Politi et al., 2019). Based on our experience (Costa-Júnior et al., 2016; Cardoso et al., 2020), the in vitro assays reported here focused on the inhibition of AChE in $R$. microplus to investigate the mode of action of essential oils from the five plants selected for this study.

\section{Conclusion}

The oils of E. globulus, C. aurantifolia, C. aurantium var. dulcis and M. piperita showed various degrees of inhibition on S.AChE and R.AChE, but only E. globulus oil inhibited rBmAChE1. The profiles of AChE inhibition for the five essential oils tested provided useful information to understand their mode of acaricidal activity, corroborating for further studies on the use of essential oils as candidates for new acaricides. Further studies are needed to determine the utility of these essential oils under field conditions to manage populations of $R$. microplus that are resistant to commercially available synthetic acaricidal chemicals. 


\section{Acknowledgements}

The U.S. Department of Agriculture is an equal opportunity employer and provider. We thank the FAPEMA (Maranhão State Research Foundation) for financial support under process UNIVERSAL-00739/17 and for awarding a fellowship to Soares, A.M.S., under process BEPP-02011/18); Santos, E.G.G and Bezerra, W.A.S. We thank CNPq (Brazilian National Council for Scientific and Technological Development) for awarding a fellowship to L.M. CostaJunior. We also thank the FINEP (Funding Authority for Studies and Projects) and FAPEMA for supporting the IECT (Science and Technology Institute of Maranhão) Biotechnology.

\section{References}

Abdelgaleil SA, Mohamed MI, Badawy ME, El-Arami SA. Fumigant and contact toxicities of monoterpenes to Sitophilus oryzae (L.) and Tribolium castaneum (Herbst) and their inhibitory effects on acetylcholinesterase activity. J Chem Ecol 2009; 35(5): 518-525. http://dx.doi.org/10.1007/s10886-009-9635-3. PMid:19412756.

Anderson JA, Coats JR. Acetylcholinesterase inhibition by nootkatone and carvacrol in arthropods. Pestic Biochem Physiol 2012; 102(2): 124-128. http://dx.doi.org/10.1016/j.pestbp.2011.12.002.

Arafa WM, Aboelhadid SM, Moawad A, Shokeir KM, Ahmed O. Toxicity, repellency and anti-cholinesterase activities of thymoleucalyptus combinations against phenotypically resistant Rhipicephalus annulatus ticks. Exp Appl Acarol 2020; 81(2): 265-277. http://dx.doi.org/10.1007/s10493-020-00506-1. PMid:32472469.

Baxter GD, Barker SC. Analysis of the sequence and expression of a second putative acetylcholinesterase CDNA from organophosphate-susceptible and organophosphate-resistant cattle ticks. Insect Biochem Mol Biol 2002; 32(7): 815-820. http:// dx.doi.org/10.1016/S0965-1748(01)00168-0. PMid:12044498.

Bradford MM. A rapid and sensitive method for the quantitation of microgram quantities of protein utilizing the principle of protein-dye binding. Anal Biochem 1976; 72(1-2): 248-254. http://dx.doi.org/10.1016/0003-2697(76)90527-3. PMid:942051.

Cardoso AS, Santos EGG, Lima ADS, Temeyer KB, Pérez De León AA, Costa LMJ, et al. Terpenes on Rhipicephalus (Boophilus) microplus: acaricidal activity and acetylcholinesterase inhibition. Vet Parasitol 2020; 280: 109090. http://dx.doi.org/10.1016/j. vetpar.2020.109090. PMid:32208306.

Carroll JF, Demirci B, Kramer M, Bernier UR, Agramonte NM, Baser KHC, et al. Repellency of the Origanum onites L. essential oil and constituents to the lone star tick and yellow fever mosquito. Nat Prod Res 2017; 31(18): 2192-2197. http://dx.doi.org/10.10 80/14786419.2017.1280485. PMid:28278656.

Chagas AC, Oliveira MC, Giglioti R, Santana RC, Bizzo HR, Gama PE, et al. Efficacy of 11 Brazilian essential oils on lethality of the cattle tick Rhipicephalus (Boophilus) microp/us. Ticks Tick Borne Dis 2016; 7(3): 427-432. http://dx.doi.org/10.1016/j.ttbdis.2016.01.001. PMid:26867819.

Costa-Júnior LM, Miller RJ, Alves PB, Blank AF, Li AY, Pérez de León AA. Acaricidal efficacies of Lippia gracilis essential oil and its phytochemical against organophosphate-resistant and susceptible strains of Rhipicephalus (Boophilus) microplus. Vet Parasitol 2016; 228: 60-64. http://dx.doi.org/10.1016/j.vetpar.2016.05.028. PMid:27692332.

Dhifi W, Bellili S, Jazi S, Bahloul N, Mnif W. Essential oils chemical characterization and investigation of some biological activities: a critical review. Medicines 2016; 3(4): 25. http://dx.doi.org/10.3390/medicines3040025. PMid:28930135.

Ellman GL, Courtney KD, Andres V Jr, Featherstone RM. A new and rapid colorimetric determination of acetylcholinesterase activity. Biochem Pharmacol 1961; 7(2): 88-95. http://dx.doi.org/10.1016/0006-2952(61)90145-9. PMid:13726518.

Ferrarini SR, Duarte MO, da Rosa RG, Rolim V, Eifler-Lima VL, von Poser G, et al. Acaricidal activity of limonene, limonene oxide and beta-amino alcohol derivatives on Rhipicephalus (Boophilus) microplus. Vet Parasitol 2008; 157(1-2): 149-153. http://dx.doi. org/10.1016/j.vetpar.2008.07.006. PMid:18755549.

Ferreira FM, Delmonte CC, Novato TLP, Monteiro CMO, Daemon E, Vilela FMP, et al. Acaricidal activity of essential oil of Syzygium aromaticum, hydrolate and eugenol formulated or free on larvae and engorged females of Rhipicephalus microplus. Med Vet Entomol 2018; 32(1): 41-47. http://dx.doi.org/10.1111/mve.12259. PMid:28833280.

George DR, Masic D, Sparagano OA, Guy JH. Variation in chemical composition and acaricidal activity against Dermanyssus gallinae of four eucalyptus essential oils. Exp Appl Acarol 2009; 48(1-2): 43-50. http://dx.doi.org/10.1007/s10493-008-9225-z. PMid:19089590.

Grisi L, Leite RC, Martins JRDS, Barros ATMD, Andreotti R, Cançado PHD, et al. Reassessment of the potential economic impact of cattle parasites in Brazil. Rev Bras Parasitol Vet 2014; 23(2): 150-156. http://dx.doi.org/10.1590/S1 984-29612014042. PMid:25054492.

Gross AD, Temeyer KB, Day TA, Pérez De León AA, Kimber MJ, Coats JR. Interaction of plant essential oil terpenoids with the southern cattle tick tyramine receptor: A potential biopesticide target. Chem Biol Interact 2017; 263: 1-6. http://dx.doi.org/10.1016/j. cbi.2016.12.009. PMid:27986436. 
Hüe T, Cauquil L, Fokou JB, Dongmo PM, Bakarnga-Via I, Menut C. Acaricidal activity of five essential oils of Ocimum species on Rhipicephalus (Boophilus) microplus larvae. Parasitol Res 2015; 114(1): 91-99. http://dx.doi.org/10.1007/s00436-014-4164-6. PMid:25300420.

Isman MB. A renaissance for botanical insecticides? Pest Manag Sci 2015; 71(12): 1587-1590. http://dx.doi.org/10.1002/ps.4088. PMid:26251334.

Li AY, Pruett JH, Davey RB, George JE. Toxicological and biochemical characterization of coumaphos resistance in the San Roman strain of Boophilus microplus (Acari: ixodidae). Pestic Biochem Physiol 2005; 81(3): 145-153. http://dx.doi.org/10.1016/j. pestbp.2004.12.002.

López V, Pavela R, Gómez-Rincon C, Les F, Bartolucci F, Galiffa V, et al. Efficacy of Origanum syriacum Essential Oil against the Mosquito Vector Culex quinquefasciatus and the Gastrointestinal Parasite Anisakis simplex, with Insights on Acetylcholinesterase Inhibition. Molecules 2019; 24(14): 2563. http://dx.doi.org/10.3390/molecules24142563. PMid:31311079.

Miresmailli S, Bradbury R, Isman MB. Comparative toxicity of Rosmarinus officinalis L. essential oil and blends of its major constituents against Tetranychus urticae Koch (Acari: Tetranychidae) on two different host plants. Pest Manag Sci 2006; 62(4): 366-371. http://dx.doi.org/10.1002/ps.1157. PMid:16470541.

Mkolo NM, Olowoyo JO, Sako KB, Mdakane STR, Mitonga MMA, Magano SR. Repellency and toxicity of essential oils of Mentha piperita and Mentha spicata on larvae and adult of Amblyomma hebraeum (Acari: ixodidae). Sci J Microbiol 2011 ; 1(1): 1-7.

Olivo CJ, Carvalho NM, Silva JHS, Vogel FF, Massariol P, Meinerz G, et al. Óleo de citronela no controle do carrapato de bovinos. Cienc Rural 2008; 38(2): 406-410. http://dx.doi.org/10.1590/S0103-84782008000200018.

Pazinato R, Volpato A, Baldissera MD, Santos RC, Baretta D, Vaucher RA, et al. In vitro effect of seven essential oils on the reproduction of the cattle tick Rhipicephalus microp/us. J Adv Res 2016; 7(6): 1029-1034. http://dx.doi.org/10.1016/j.jare.2016.05.003. PMid:27857849.

Pérez de León AA, Mitchell RD 3rd, Watson DW. Ectoparasites of cattle. Vet Clin North Am Food Anim Pract 2020; $36(1): 173-185$. http://dx.doi.org/10.1016/j.cvfa.2019.12.004. PMid:32029183.

Pinto ZT, Sánchez FF, Santos AR, Amaral AC, Ferreira JL, Escalona-Arranz JC, et al. Chemical composition and insecticidal activity of Cymbopogon citratus essential oil from Cuba and Brazil against housefly. Rev Bras Parasitol Vet 2015; 24(1): 36-44. http://dx.doi. org/10.1590/S1984-29612015006. PMid:25909251.

Politi FAS, Fantatto RR, da Silva AA, Moro IJ, Sampieri BR, Camargo-Mathias MI, et al. Evaluation of Tagetes patula (Asteraceae) as an ecological alternative in the search for natural control of the cattle tick Rhipicephalus (Boophilus) microplus (Acari: ixodidae). Exp Appl Acarol 2019; 77(4): 601-618. http://dx.doi.org/10.1007/s10493-019-00368-2. PMid:31076974.

Prado-Ochoa MG, Ramírez-Noguera P, Díaz-Torres R, Garrido-Fariña Gl, Vázquez-Valadez VH, Velázquez-Sánchez AM, et al. The action of two ethyl carbamates on acetylcholinesterase and reproductive organs of Rhipicephalus microplus. Vet Parasito/ 2014; 199(3-4): 215-224. http://dx.doi.org/10.1016/j.vetpar.2013.10.028. PMid:24315691.

ReckJ, Klafke GM, Webster A, Dall'agnol B, Scheffer R, Souza UA, et al. First report of fluazuron resistance in Rhipicephalus microplus: a field tick population resistant to six classes of acaricides. Vet Parasitol 2014; 201(1-2): 128-136. http://dx.doi.org/10.1016/j. vetpar.2014.01.012. PMid:24560364.

Reginato CZ, Cadore GC, Menezes FRD, Sangioni LA, Vogel FSF. Efficacy of commercial synthetic pyrethroids and organophosphates associations used to control Rhipicephalus (Boophilus) microplus in Southern Brazil. Rev Bras Parasitol Vet 2017; 26(4): 500-504. http://dx.doi.org/10.1590/s1984-29612017054. PMid:29091122.

Rodriguez-Vivas RI, Jonsson NN, Bhushan C. Strategies for the control of Rhipicephalus microplus ticks in a world of conventional acaricide and macrocyclic lactone resistance. Parasitol Res 2018; 117(1): 3-29. http://dx.doi.org/10.1007/s00436-017-5677-6. PMid:29152691.

Roy BC, Krucken J, Ahmed JS, Majumder S, Baumann MP, Clausen PH, et al. Molecular identification of tick-borne pathogens infecting cattle in Mymensingh district of Bangladesh reveals emerging species of Anaplasma and Babesia. Transbound Emerg Dis 2018; 65(2): e231-e242. http://dx.doi.org/10.1111/tbed.12745. PMid:29119682.

Salleh W, Khamis S. Chemical composition and anticholinesterase inhibitory activity of Pavetta graciliflora Wall. ex Ridl. essential oil. Z Naturforsch 2020; 75(11-12): 467-471. http://dx.doi.org/10.1515/znc-2020-0075. PMid:32469335.

Salman M, Abbas RZ, Israr M, Abbas A, Mehmood K, Khan MK, et al. Repellent and acaricidal activity of essential oils and their components against Rhipicephalus ticks in cattle. Vet Parasito/ 2020; 283: 109178. http://dx.doi.org/10.1016/j.vetpar.2020.109178. PMid:32652458.

Sharifi M, Ghadamyari M, Gholivand K, Valmoozi AAE, Sajedi RH. Characterization of acetylcholinesterase from elm left beetle, Xanthogaleruca luteola and QSAR of temephos derivatives against its activity. Pestic Biochem Physiol 2017; 136: 12-22. http:// dx.doi.org/10.1016/j.pestbp.2016.08.010. PMid:28187825. 
Silva Lima A, Milhomem MN, Santos Monteiro O, Arruda ACP, Castro JAM, Fernandes YML, et al. Seasonal analysis and acaricidal activity of the thymol-type essential oil of Ocimum gratissimum and its major constituents against Rhipicephalus microplus (Acari: ixodidae). Parasitol Res 2018; 117(1): 59-65. http://dx.doi.org/10.1007/s00436-017-5662-0. PMid:29152690.

Singh NK, Jyoti, Vemu B, Nandi A, Singh H, Kumar R, et al. Acaricidal activity of Cymbopogon winterianus, Vitex negundo and Withania somnifera against synthetic pyrethroid resistant Rhipicephalus (Boophilus) microplus. Parasitol Res 2014a; 113(1): 341-350. http:// dx.doi.org/10.1007/s00436-013-3660-4. PMid:24178747.

Singh NK, Jyoti, Vemu B, Nandi A, Singh H, Kumar R, et al. Laboratory assessment of acaricidal activity of Cymbopogon winterianus, Vitex negundo and Withania somnifera extracts against deltamethrin resistant Hyalomma anatolicum. Exp Appl Acarol 2014b; 63(3): 423-430. http://dx.doi.org/10.1007/s10493-014-9791-1. PMid:24647800.

Soares AMS, Penha TA, Araújo SAD, Cruz EMO, Blank AF, Costa-Junior LM. Assessment of different Lippia sidoides genotypes regarding their acaricidal activity against Rhipicephalus (Boophilus) microplus. Rev Bras Parasitol Vet 2016; 25(4): 401-406. http:// dx.doi.org/10.1590/s1984-29612016087. PMid:27982301.

Stefanidesová K, Skultéty L, Sparagano OAE, Spitalská E. The repellent efficacy of eleven essential oils against adult Dermacentor reticulatus ticks. Ticks Tick Borne Dis 2017; 8(5): 780-786. http://dx.doi.org/10.1016/j.ttbdis.2017.06.003. PMid:28645519.

Temeyer KB, Pruett JH, Olafson PU. Baculovirus expression, biochemical characterization and organophosphate sensitivity of rBmAChE1, rBmAChE2, and rBmAChE3 of Rhipicephalus (Boophilus) microplus. Vet Parasitol 2010; 172(1-2): 114-121. http://dx.doi. org/10.1016/j.vetpar.2010.04.016. PMid:20451328.

Temeyer KB, Schlechte KG, Olafson PU, Drolet BS, Tidwell JP, Osbrink WLA, et al. Association of salivary cholinesterase with arthropod vectors of disease. J Med Entomo/ 2020; 57(6): 1679-1685. http://dx.doi.org/10.1093/jme/tjaa096. PMid:32459332.

Temeyer KB, Tuckow AP, Brake DK, Li AY, Pérez De León AA. Acetylcholinesterases of blood-feeding flies and ticks. Chem Biol Interact 2013; 203(1): 319-322. http://dx.doi.org/10.1016/j.cbi.2012.09.010. PMid:23036311.

Temeyer KB. Molecular biology of tick acetylcholinesterases. Front Biosci 2018; 23(4): 1320-1337. http://dx.doi.org/10.2741/4646. PMid:28930602.

Valente PP, Moreira GHFA, Serafini MF, Facury-Filho EJ, Carvalho AU, Faraco AAG, et al. In vivo efficacy of a biotherapic and eugenol formulation against Rhipicephalus microp/us. Parasitol Res 2017; 116(3): 929-938. http://dx.doi.org/10.1007/s00436-0165366-x. PMid:28058537.

Vinturelle R, Mattos C, Meloni J, Nogueira J, Nunes MJ, Vaz IS Jr, et al. In Vitro Evaluation of essential oils derived from Piper nigrum (Piperaceae) and Citrus limonum (Rutaceae) against the tick Rhipicephalus (Boophilus) microplus (Acari: ixodidae). Biochem Res Int 2017; 2017: 5342947. http://dx.doi.org/10.1155/2017/5342947. PMid:29123924.

Wang HH, Teel PD, Grant WE, Soltero F, Urdaz J, Pérez Ramírez AE, et al. Simulation tools for assessment of tick suppression treatments of Rhipicephalus (Boophilus) microplus on non-lactating dairy cattle in Puerto Rico. Parasit Vectors $2019 ; 12(1)$ : 185. http://dx.doi.org/10.1186/s13071-019-3443-6. PMid:31029149. 